\title{
The invertebrate's community in adjacent Alto Iguaçu's anthropic lakes of different environmental factors
}

\author{
Ana Carolina de Deus Bueno Krawczyk ${ }^{1,3}$, Lucíola Thais Baldan', \\ José Marcelo Rocha Aranha², Márcia Santos de Menezes ${ }^{2} \&$ Cyntia Vilasboas Almeida $^{2}$ \\ ${ }^{I}$ Grupo de pesquisa Ecologia de Rios e Biomonitoramento, Departamento de Ciências Biológicas, \\ Universidade Estadual do Paraná - UNESPAR, Campus FAFIUV, Praça Coronel Amazonas, s/n, \\ CEP 84600-000, União da Vitória, PR, Brazil \\ ${ }^{2}$ Universidade Federal do Paraná - UFPR, Rua Pioneiro, 2153, Jardim Dallas, \\ CEP 85950-000, Palotina, PR, Brazil \\ ${ }^{3}$ Corresponding author: Ana Carolina de Deus Bueno Krawczk, e-mail: bueno_acd@yahoo.com.br
}

KRAWCZYK, A.C.D.B., BALDAN, L.T., ARANHA, J.M.R., MENEZES, M.S. \& ALMEIDA, C.V. The invertebrate's community in adjacent Alto Iguaçu's anthropic lakes of different environmental factors. Biota Neotrop. 13(1): http://www.biotaneotropica.org.br/v12n4/en/abstract?article+bn00813012013

\begin{abstract}
Environmental differences occur between lentic and lotic communities' establishment, especially because of water time residence. Here we used a combination of field measurements and statistical analysis to evaluate the influent factors on the aquatic macroinvertebrates' composition and structure in 15 anthropogenic lakes from Alto Iguaçu's region. Macroinvertebrates were sampled from the marginal vegetation (with or without macrophytes) and sediment. Chemical parameters ranged among the anthropogenic lakes, mainly those which are connected to the Iguaçu River, beyond the presence or absence of macrophytes, interfering on the community's structure. Lake's morphometric data were measured in each lake and its relation to community was tested. The community structure was not related to the margin development index (Ds), macrophytes and altitude. Higher equitability was associated to the macrophytes presence in more than $30 \%$ of water surface and also where the riparian vegetation was more complex. Chironomids and oligochaetes densities were associated to lakes with the water surface completely covered by macrophytes and complex riparian vegetation. We observed a close association between productivity (phosphorous and nitrogen) and the community equitability $(\mathrm{R}=0.3 ; \mathrm{p}<0.05)$ and Oligochaeta dominance $(\mathrm{R}=0.32 ; \mathrm{p}<0.05)$, and not to Ostracoda's $(\mathrm{R}=0.33 ; \mathrm{p}>0.05)$ and Chironomidae's $(\mathrm{R}=0.34 ; \mathrm{p}>0.05)$ dominances, although we had not weighty difference among analyzed biological indexes. The obtained values from the BMWP' and EPT indexes resulted in acceptable, doubtful or critical water quality, what corroborates with the macroinvertebrate's structure of the composition and with the environmental variables observed in field.
\end{abstract}

Keywords: freshwater invertebrates, Iguaçu River, productivity, macrophytes, tropical lakes.

KRAWCZYK, A.C.D.B., BALDAN, L.T., ARANHA, J.M.R., MENEZES, M.S. \& ALMEIDA, C.V. A comunidade de invertebrados em lagos antrópicos adjacentes com diferentes fatores ambientais no Alto Iguaçu. Biota Neotrop. 13(1): http://www.biotaneotropica.org.br/v13n1/pt/abstract?article+bn00813012013

Resumo: Diferenças ambientais ocorrem entre o estabelecimento de comunidades de ambientes lênticos e lóticos, especialmente por causa do tempo de residência da água. Foi usada uma combinação de métricas de campo e análise estatística para avaliar os fatores influentes sobre a composição e estrutura de macroinvertebrados aquáticos em 15 lagos antropogênicos da região do Alto Iguaçu. Os macroinvertebrados foram amostrados da vegetação marginal (com ou sem macrófitas) e sedimento. Parâmetros químicos variaram entre os lagos antrópicos, principalmente aqueles conectados ao Rio Iguaçu, além da presença ou ausência das macrófitas, interferindo na estrutura da comunidade. Dados de morfometria de lagos foram mensurados e sua relação com a comunidade foi testada. A estrutura da comunidade não foi relacionada ao índice de desenvolvimento da margem (Ds), macrófitas e altitude. Maior equitabilidade foi associada à presença de macrófitas em mais de $30 \%$ da superfície da água e também onde a vegetação ripária foi mais complexa. Densidades de quironomídeos e oligoquetas foram associadas a lagos com a superfície completamente coberta por macrófitas e complexa vegetação ripária. Foi observada associação entre a produtividade (fósforo e nitrogênio) e a equitabilidade da comunidade $(\mathrm{R}=0.3 ; \mathrm{p}<0.05)$ e dominância de Oligochaeta $(R=0.32 ; p<0.05)$ e não para a dominância de Ostracoda $(R=0.33 ; p>0,05)$ e Chironomidae $(\mathrm{R}=0.34 ; \mathrm{p}>0.05)$, apesar de não haver diferença entre os índices biológicos analisados. Os valores obtidos através do Índice BMWP' e EPT/C resultaram em ambientes de qualidade aceitável, duvidosa ou crítica, o que corrobora com a estrutura da composição de invertebrados e com as características ambientais observadas em campo.

Palavras-chave: invertebrados dulcícolas, Rio Iguaçu, produtividade, macrófitas, lagos tropicais. 


\section{Introduction}

Freshwater ecosystems are characterized by two types of environments, lotic and lentic, which differ primarily in relation to their flux and water residence time. In a lentic environment, water residence time can be up to 10 years. Generally shallow tropical environment characteristics do not contribute to physical and chemical stratification (Esteves 1998).

Lakes can be classified according to their productivity, which takes account the primary productivity, and this, in turn, is related to how the nutrients arrive, and the depth. Since these data, it is possible to determine the environment trophic state (Odum 2001). Several researches determine the trophic state considering the available phosphorous and nitrogen concentrations (Dodds 2003), since these nutrients are limiting for plants (Trayler 2000). Tropical lentic environments tend to have higher phosphorous concentration than nitrogen, because of edaphic and climatic characteristics (Wetzel 2001). High macrophytes abundance take to nitrogen depletion, because of dissolved oxygen reduction, leading to denitrification, and, still in lower quantities, the production goes on in tropical freshwaters, which means in these environments the nutrient cycling is very efficient, as well the primary productivity (Kolding \& Zwieten, 2006). Studies show a direct relationship between chlorophyll and phosphorous (Smith 1982), and Quiros (2002) states that the algal biomass reaches its peak with overload of total phosphorous. Furthermore, nutrients overload lead to these environments by runoff and point source of pollution (Rivas et al. 2000), reducing the water column and increasing the autochthonous production (Rast \& Thornton 1996). Thus, littoral regions in lakes tend to have higher productivity and fauna diversity than limnetic and profundal regions (Tundisi \& Matsumura-Tundisi 2008).

Biological community colonization and establishment in ponds have a determining factor of habitat conditions (Marques et al. 1999). Thus, the floodplain physical, chemical and morphological measures condition these communities (Junk et al. 1989, Carignan \& Neiff 1992, Neiff et al. 2001), whereas the horizontal movement of the river could flood the ponds and, consequently, there is exchange of water and materials. This exchange ensures selective pressure on the species of wetland areas, allowing a community composed by organisms with broad physiological plasticity, which survive in an intense spatial and temporal variations habitat (Neiff 1975, Poi de Neiff \& Bruquetas de Zozaya 1989).

Anthropic lakes are remaining holes on the ground excavated for sand extraction, which once abandoned, are drained by the catchment area and form the water mirrors (Lelles et al. 2005). Although the formation of water features by mining is characteristic of a changed environment, the presence of vegetation around the lakes and the physical chemical characteristics favor the macroinvertebrates colonization in these lentic systems in development (Moletta et al. 2005). These shallow lakes with reduced areas are influenced by any changes in environmental conditions, and this is reflected on water quality and aquatic community structure. After a big flooding in 1995, some works, like the channel's rectification and the construction of dikes on the floodplain and the secondary channel, were alternatives to reduce the recurring floods that affected the population in nearby areas (Superintendência... 2007). The secondary channel was constructed in order to provide greater depth, parallel to the river. When entering in the metropolitan Curitiba's region, the riverbed was modified, providing extension and depth, in many points it remakes the riverbed or cut the natural one, transforming the meanders in to horseshoe lakes.

Brauns et al. (2007) argue that while domestic and industrial discharges have been reduced in recent years, due to wastewater treatment, the lakes still receive nitrogen from urban areas, and phosphorous from agricultural waste, besides atmospheric deposition. According to Vollenweider (1968) the increase of nutrients, particularly phosphorus, enriches the environment and favors the algal blooms, which can reduce the development of submerged plants (Chandra et al. 2005). These, in turn, are important for aquatic mesohabitats because they play an important ecological role regarding the availability of food, refuge place and nutrient cycling (Biggs \& Malthus 1982, Esteves 1998, Alves et al. 2003, Thomaz \& Cunha 2010).

The aquatic invertebrates' communities are represented by a heterogeneous group of taxa, with approximately $0,5 \mathrm{~mm}$ of length, which survives associated to the deep substratum (Mugnai et al. 2010). These communities are very important to the understanding about aquatic ecosystems (Cummins 1992) and have been used as pollution bioindicator in these, because of their wild distribution, abundance and easy to collect. These animals are relatively sedentary, and, because of this, can show a local integrity situation; besides, they have a long life cycle, being able to register the environmental quality (Metcalfe, 1989).

Its taxonomic diversity as well its different tolerance to organic enrichment permits inferences about the use of this community in environmental integrity analysis (Rosenberg \& Resh 1993, Merrit \& Cummins 1996). In shallow lakes, these taxa also act like metabolism ecosystem's facilitator because they participate in nutrient cycling, reducing the organic particles sizes, which improves the decomposition process to the microorganisms (Vannote et al. 1980, Keast 1985, Mcqueen et al. 1986, Berg et al. 1997, Silva et al. 2009). These taxa's occurrence in sediment and marginal/riverine vegetation (Botts \& Cowell 1993, Kurashov 1996) favors an extensive analysis from the ecosystem conditions because of the different patterns displayed by the community in response to the physical and chemical parameters, making it possible to understand how the ecosystem alterations influence the attributes richness, composition and density (Goulart \& Callisto 2003, Bonada et al. 2006).

Aquatic community classification is complicated because of lack of information about the measures that regulate the species abundance and distribution. Thus, Frissel et al. (1996) attribute community regulations to geomorphological patterns, and highlight the landscape influence in shallow aquatic ecosystems such as ponds, small lakes and coastal waters. In this context, the assessment of environmental parameters governing the distribution and abundance of invertebrate taxa in the ponds can show the most closely related variables to macroinvertebrates community (Sandin \& Johnson 2004), and they allow the selection of monitoring methods that bring faster results and address the environmental conditions that are more related to the macroinvertebrates community attributes.

In lakes, the littoral region is the one which shows the biggest nutrient cycle and the highest organism's diversity, especially because of the vegetation, that supplies higher organisms' richness and diversity (Ward 1992). Callisto et al. (2000), comparing different regions, found that occurred highest diversity at the littoral region with secondary Atlantic forest, followed by the limnetic and littoral regions with eucalyptus, which evidences the around importance correlated to the fauna composition. Nascimento et al. (2011) showed that the highest beetles' diversity was associated to shallow environments, especially with the macrophytes presence, which are considered essential factors for the specie's diversity, settlement in shallow subtropical lakes, increasing the habitat heterogeneity, offering resource and refugee, especially to invertebrates (Hargeby 1990, Nessimian \& De Lima 1997, Albertoni et al. 2007).

Thus, this study aimed to search factors that influence macroinvertebrates community composition and structure in 
15 anthropogenic lakes in the First Plateau region of the Iguaçu River (Upper Iguaçu), Curitiba, Paraná.

The assumption guiding the work is that attributes of the invertebrates' community suffer the effects of the morphometric characteristics, water quality and landscape conditions of the lakes (marginal/riverine vegetation and macrophytes).

\section{Materials and Methods}

\section{Study area}

The sample points were from the First Paranaense Plateau, characterized by a broad Upper Iguaçu plain surrounded by gently rolling relief with wavy forms (Maack 1981), under the $C f b$ climate influence.

This work was carried out in an area with anthropogenic lakes, where 12 was chosen, derived from sand extraction was transformed into a park, and three were from recently closed river branches from the Iguaçu river, formed by anthropogenic changes to bridge construction or river course alteration in order to reduce the flooding, in Curitiba (Paraná state) (Figure 1).

\section{Physical and chemical water analysis}

Water and air temperature were measured in field. It was done one water sample from each lake, during the dry period (july/2009), and it was taken to the Laboratório de Hidrologia of the UFPR in order to be processed. The analyzed parameters were: Turbidity (NTU, nephelometric method), Dissolved Oxygen (DO) $\left(\mathrm{mgO}_{2} / \mathrm{L}\right.$, Winkler Method), hidrogenionic potential $(\mathrm{pH})$, Biochemical Oxygen Demand $\left(\mathrm{BO}_{5} \mathrm{D}\right)\left(\mathrm{mgO}_{2} / \mathrm{L}\right.$, Winkler Method), Orthophosphate $(\mu \mathrm{g} / \mathrm{L}$, spectrophotometer), Total Phosphate (TP) $(\mu \mathrm{g} / \mathrm{L}$, spectrophotometric Stannous Chloride, Nitrite $(\mu \mathrm{g} / \mathrm{L}$, Sulfanilamide and N-(1-Naftil) Etilenodiamine), Nitrate $(\mu \mathrm{g} / \mathrm{L}$, spectrophotometric), Ammonia Nitrogen ( $\mu \mathrm{g} / \mathrm{L}$, Macro Kjendahl), Total Nitrogen (TP) ( $\mu \mathrm{g} / \mathrm{L}$, spectrophotometer) e Dissolved Organic Carbon (mg/L, spectrophotometer). All the analyses were performed by the methodology proposed by Standard Methods (American... et al. 2005)

\section{Invertebrates}

Invertebrates were sampled from macrophytes/marginal vegetation using a $0.05 \mathrm{~mm}$-mesh screen $(30 \times 30 \mathrm{~cm})$ and the sample protocol included the introduction of the sieve under the marginal vegetation's roots and macrophytes in each replica, and all the material was collected by the sieve in order to happen the screening in the laboratory. The sediment sample was done using a Ponar type Grab sampler $(15 \times 15 \mathrm{~cm})$, with three replicas for each sample point In each lake, the substrate sample occurred in random places, and that the taken macrophytes had about 10 meters of distance from one to other. All the replicas were taken during the dry period (july/2009). The material screening was done on light box and all the organisms were identified to the lowest possible taxonomic resolution, mostly in genus level (Pérez 1988, Trivinho-Strixino \& Strixino 1995, Merrit \& Cummins 1996, Wiggins 1996, Mugnai et al. 2010).

\section{Area characterization}

The fifteen lakes considered in this work are from an area with $2.05 \mathrm{~km}^{2}$, from which twelve are coming from sand extraction and were transformed in a recreational park, two of lakes are Iguaçu River's arms that were closed with the secondary channel's construction, which was held to increase the riverbed and reduce the frequency of flooding, and one of them was established because of a bridge construction, in Curitiba city.

The sample point's choice was done according to environmental different characteristics about macrophytes and riparian vegetation (Instituto... 2004) in the lakes, being, yet, characterized according to the geographic localization. The macrophyte proportion on the water surface (MF), marginal/riverine vegetation (RV) and period of lake's establishment were measured. The macrophytes proportion was measured by values between 0 and $100 \%$, with the following range of values: score 1 for 1 to $20 \%$ of macrophytes on the water surface $(* 1)$; score 2 for 21 to $40 \%$ of macrophytes on the water surface $(* 2)$; score 3 for 41 to $70 \%$ of macrophytes on the water surface $(* 3)$; score 4 for 71 to $100 \%$ of macrophytes on the water surface $(* 4)$. The riverine vegetation was measured according to the plant's absence, only grass presence, grass and bushes' presence or by grass, bush and tree's presence, following the range of values: 1 for shrub with predominance of grass $(* * 1) ; 2$ for shrubs that allow little shading $(* * 2)$; 3 for intact vegetation $(* * 3)$.

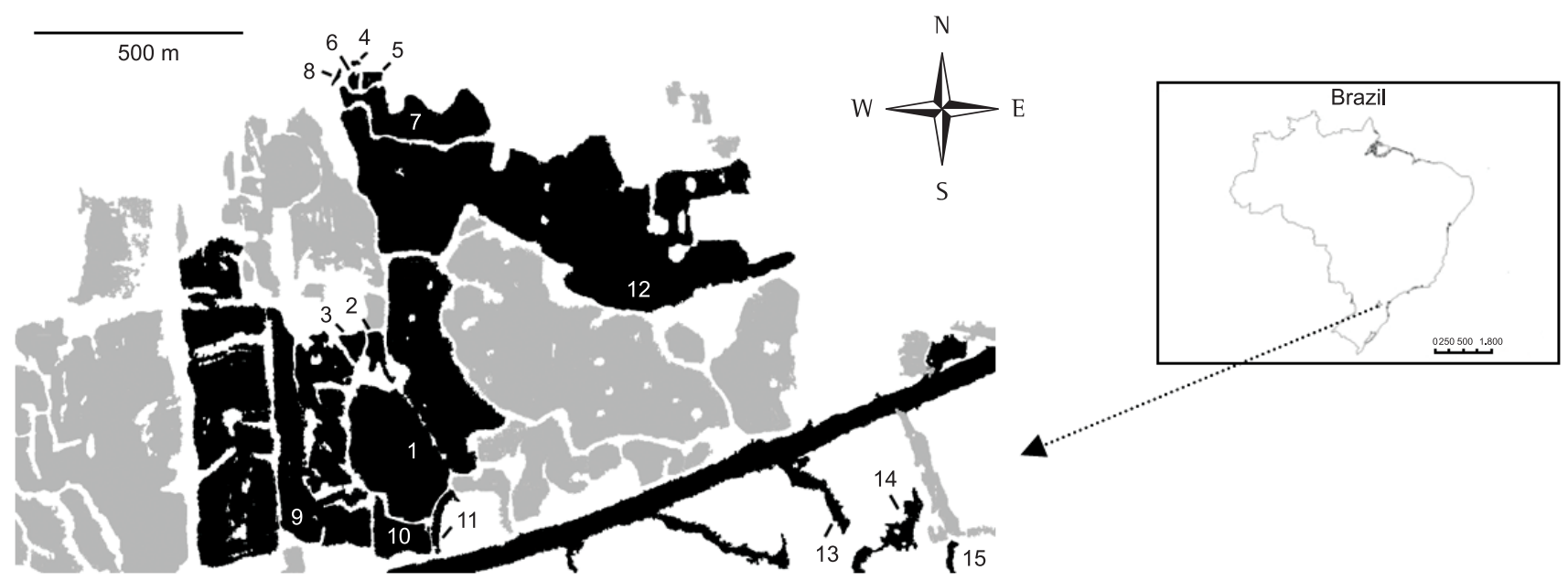

Figure 1. Location of study area. The sample points are numbered. Water bodies in black represent the sample points and the water bodies in gray, the adjacent sample points. 


\section{Morphometric characteristics of the lakes}

The depth was obtained by the registered measure to dry period (july/2009) to the area according to the area's monitor. The lakes and surrounding area were marked in GPS and georeferenced using ERDAS software. The data adjust allowed the generation of a hypsometric map.

From ground numerical model, polygons were established in order to verify primary morphometric data, such as area and perimeter, and from this the development margin index (Ds) was calculated in order to determinate the lake's form (Wetzel 1990, Tundisi \& Matsumura-Tundisi 2008). The Ds followed the equation: Ds $=\mathrm{L} / 2 \sqrt{\Pi A}$, where L represents the polygon length (from each sample point) and A represents the circle circumference with the same lake area. The response values can be close or far from one (1). Thus, when the development margin index is closer to one, the lake tend to have a circular pattern, and the values far from one tend to be more elongated with dendritic pattern (between 3 and 5).

\section{Data analysis}

To the physical and chemical lakes' characterization the mean and standard deviation were calculated to the fifteen samples and the variation coefficient (VC) was defined. As a sample's variability standard of the quantitative factors was established that the lower variation coefficient of $20 \%$ denoted homogeneity conditions, whereas equal or upper than $20 \%$ denoted heterogeneous factors.

The community structure was checked on parameters of richness (number of taxa identified per sample unit - S), occurrence frequency (OF), Shannon-Wiener diversity index, which considers the community's biomass in relation to taxonomic richness $(\mathrm{H})$, Margalef's richness, that was referred about the number of genus in the samples, (d), Pielou equitability (J'), dominance (Dm) and relative abundance. These attributes were calculated using the statistical pack Past $^{\mathbb{B}}$ (Hammer et al. 2007).

ANOVA was applied using Past ${ }^{\circledR}$ computer program (Hammer et al. 2007) to verify differences in community attributes calculated for the 15 sample points. The data met the normality and homogeneity assumptions, prior tested for variance analysis.

The correlation between nitrogen and phosphorous was done according the Vollenweider (1983) proposal, being that the total nitrogen related to phosphorous ratio determine the environment's limitation because of one of these elements. According to this method, with a ratio higher than nine, the lakes are limited by phosphorous, while ratio lower than nine, characterizes lakes limited by nitrogen.

In order to test the most influent environmental variables on the community attributes, the Partial Least Squares (PLS) (Carrascal et al. 2009) was used, with the aid of Statistica ${ }^{\circledR} 7.0$ (StatSoft 2005) for the 15 samples points, with two dependent variable models, equitability (J') and the most dominant taxa obtained, seeking the best descriptors to explain structure and composition of the macroinvertebrates community. The statistical variables (factors) are composed by linear offsets relationships between the observed variables and the classification according to ecological significance, which must be based on literature concepts (Hair et al. 2009).

To infer about the water quality using the macroinvertebrate's community it was done the BMWP' index (Biological Monitoring Work Party System), modified by Toniolo et al. (2001), which considers the macroinvertebrate's tolerance to organic matter, and EPT (Ephemeroptera, Plecoptera and Trichoptera), which considers these taxa proportions among other taxonomic groups (Silveira 2004). In this work, the comparison of EPT was with Chironomidae taxon.

\section{Results}

MF1 represented the macrophytes occurrence between $0-25 \%$ of water surface, MF2 was to an occurrence of $26-51 \%$, MF3 was to $52-75 \%$ of occurrence, and MF4 was to an occurrence between $76-100 \%$. So, MF4 has occurred in $46 \%$ of the points, whereas more than $50 \%$ of the points did not have expressive macrophytes contribution (MF1, MF2, MF3). The vegetation presence surrounding was carried out in four intervals according to the main composition, where grass and shrubs composed (RV2) 46\% of lakes, whereas complex vegetation, which composition was of grass, shrubs and trees (RV3), occurred in 40\%. The exclusive grass presence in composition (RV1) and the absence of plants around (RV0) occurred only in $14 \%$ of the sampled lakes (Table 1,2). The margin development index (Ds) presented perfectly circular (Ds1) (26\%) and circular (Ds2) $(66.6 \%)$ patterns in most. Dendritic pattern (Ds3) was the least occurrence (6.6\%) (Table 2).

There was little variation about parameters water temperature, altitude and $\mathrm{pH}$ among the sampled lakes $(\mathrm{VC}=3 \%, 0,1 \%$ and $4 \%$, respectively). The other limnological variables were heterogeneous among the lakes, being the variation coefficient to the $\mathrm{DO}=39 \%$, $\mathrm{DOC}=65 \%$, total phosphate $=89 \%, \mathrm{BO}_{5} \mathrm{D}$ and orthophosphate $=94 \%$, turbidity $=116 \%$, nitrite $=153 \%$, total nitrogen $=164 \%$ (Table 3 ).

The Table 3 also shows the nitrogen phosphorous ratio, demonstrating that eleven of the fifteen sample points are limited by phosphorous. The highest ratio was observed in lakes without macrophytes (PT3 and PT13). The sample points PT5, PT8, PT11 and PT14 were limited by nitrogen. The points PT8, PT11 and PT14 had a large amount of macrophytes, which are very efficient in nitrogen fixation.

The fauna of both lakes was composed by 9054 macroinvertebrates, distributed in 133 taxa, between family and genus taxonomic levels (Figure 2). The insects were identified, always that possible, in genus level (Table 4) and the other individuals, to the lowest possible taxonomic level (Table 5).

Oligochaeta $(48.1 \%)$ and Chironomidae $(17.16 \%)$ were the most abundant in community, and both taxa were registered in all of sampled points. Chironomidae presented the highest percentage abundance among collected insects (17.6\%). The genus Monopelopia $s p$. (Diptera: Chironomidae: Tanypodinae) was a strong contributor to macroinvertebrates community in the three most abundant sample points.

The PT14 presented the higher abundance, with 1442 organisms, being oligochaets (675) and quironomids (490) the most abundant taxa, followed by points PT4 (1429) and PT15 (881). PT15 had the highest richness (58), and also Margalef index. Oligochaeta was the most abundant in PT15 too. It is relevant to consider that points PT14 and PT15, besides abundant macrophytes presence and complex riparian vegetation, these points receive Iguaçu river's water during flood period.

Ecological indexes were not weighty different among the 15 sampled points (ANOVA) $(\mathrm{F}=0.49 ; \mathrm{df}=22.17 ; p=0.90)$. Each one presented a peculiar pattern about the macroinvertebrates community attributes variation. The highest diversity was obtained to PT15, whereas the lowest, in PT13. Lowest dominance occurred in PT11 and PT7, as well, the highest equitability values (Table 6).

There was little range among richness, dominace, Margalef richness and equitability. In all cases, the range was very close to mean, being registered to richness the mean $34(\mathrm{sd}=13.4)$, to dominance, mean of 0.3 ( $\mathrm{sd}=0.1)$, to Margalef's richness mean of $5.4(\mathrm{sd}=1.5)$ and to equitability, the mean of $0.5(\mathrm{sd}=0.1)$. The individuals abundance $(\mathrm{N})$ presented the highest range among the sampled lakes, $556(\mathrm{sd}=424.3)($ Table 7). 
Aquatic Invertebrate's community in lakes from the Alto Iguaçu

Table 1. Descriptive characteristics from the 15 sample points where MF $=$ macrophytes presence $(* 1-$ from 1 to $20 \%$ of water surface covering; $* 2-$ from 21 to $40 \%$ of water surface covering; $* 3$ - from 41 to $70 \%$ of water surface covering; $* 4$ - from 71 to $100 \%$ of water surface covering) and RV $=$ riparian vegetation $(* * 1-$ bushes, with more grass; $* * 2$ - bushes that ensure little shadowing; $* * 3-$ intact vegetation).

\begin{tabular}{|c|c|c|c|c|}
\hline & Location & MF & RV & Characteristics \\
\hline PT1 & $\begin{array}{l}25^{\circ} 36.406 " \mathrm{~S} \\
49^{\circ} 17.435^{\prime \prime} \mathrm{W}\end{array}$ & All water surface $* 3$ & Trees and bushes $* * 2$ & Establishment of the lagoon:30 years \\
\hline PT 2 & $\begin{array}{l}25^{\circ} 36.360 " \mathrm{~S} \\
49^{\circ} 17.456 ” \mathrm{~W}\end{array}$ & Near the margins* 3 & Trees and bushes $* * 2$ & Establishment of the lagoon: 30 years \\
\hline PT 3 & $\begin{array}{l}25^{\circ} 36.360^{\prime \prime} \mathrm{S} \\
49^{\circ} 17.456 ” \mathrm{~W}\end{array}$ & Absent*1 & Grass $* * 1$ & Establishment of the lagoon: 30 years \\
\hline PT 4 & $\begin{array}{l}25^{\circ} 36.099 " \mathrm{~S} \\
45^{\circ} 17.299 ” \mathrm{~W}\end{array}$ & All water surface*4 & Bushes and grass $* * 1$ & \\
\hline PT 5 & $\begin{array}{l}25^{\circ} 36.100^{\prime \prime} \mathrm{S} \\
49^{\circ} 17.299 " \mathrm{~W}\end{array}$ & Near the margins (up to $30 \%$ ) $* 2$ & $* * 1$ & Brickwork on one margin \\
\hline PT 6 & $\begin{array}{l}25^{\circ} 36.109 " \mathrm{~S} \\
49^{\circ} 17.304 " \mathrm{~W}\end{array}$ & Near the margins (up to $30 \%$ ) $* 2$ & Grass $* * 1$ & Brickwork all around it \\
\hline PT 7 & $\begin{array}{l}25^{\circ} 36.136 " \mathrm{~S} \\
49^{\circ} 17.298 " \mathrm{~W}\end{array}$ & All water surface $* 4$ & Bushes and grass $* * 1$ & $\begin{array}{l}30 \text { years } \\
\text { Presence of erosion } \\
\text { Brickwork on the margin }\end{array}$ \\
\hline PT 8 & $\begin{array}{l}25^{\circ} 36.114 " \mathrm{~S} ; \\
49^{\circ} 17.342 " \mathrm{~W}\end{array}$ & Almost all water surface $(50 \%) * 3$ & Trees and bushes $* * 2$ & Not deep; River's fragment \\
\hline PT 9 & $\begin{array}{l}25^{\circ} 36.690 " \mathrm{~S} ; \\
49^{\circ} 17.423 ” \mathrm{~W}\end{array}$ & $50 \%$ of water surface $* 3$ & Trees $* * 2$ & \\
\hline PT 10 & $\begin{array}{l}25^{\circ} 38.718 " \mathrm{~S} \\
49^{\circ} 17.201 " \mathrm{~W}\end{array}$ & $40 \%$ of water surface $* 2$ & Bushes and trees $* * 2$ & Next to the Iguaçu river canal \\
\hline PT 11 & $\begin{array}{l}25^{\circ} 36.700^{\prime \prime} \mathrm{S} \\
49^{\circ} 17.197^{\prime \prime} \mathrm{W}\end{array}$ & All water surface $* 4$ & Complex vegetation $* * 3$ & $\begin{array}{l}\text { Old part of the river, next to the river } \\
\text { canal }\end{array}$ \\
\hline PT 12 & $\begin{array}{l}25^{\circ} 36.397 " \mathrm{~S} \\
49^{\circ} 16.845^{\prime \prime} \mathrm{W}\end{array}$ & Absent $* 1$ & Bushes and grass $* * 1$ & \\
\hline PT 13 & $\begin{array}{l}25^{\circ} 36.684 " \mathrm{~S} ; \\
49^{\circ} 16.605 ” \mathrm{~W}\end{array}$ & Absent $* 1$ & Complex vegetation $* * 3$ & $\begin{array}{l}\text { Iguaçu river's arm; Erosion } \\
\text { Decomposition odor; }\end{array}$ \\
\hline PT 14 & $\begin{array}{l}25^{\circ} 36.649^{\prime \prime} \mathrm{S} \\
49^{\circ} 16.494 ” \mathrm{~W}\end{array}$ & $\begin{array}{l}\text { All water surface } * 4 \text { Diverse } \\
\text { macrophyte groups present }\end{array}$ & Complex vegetation $* * 3$ & $\begin{array}{l}\text { Presence of erosion } \\
\text { Iguaçu river's arm }\end{array}$ \\
\hline PT 15 & $\begin{array}{l}25^{\circ} 36.681 " \mathrm{~S} \\
49^{\circ} 16.491 ” \mathrm{~W}\end{array}$ & Almost all water surface $* 4$ & Complex vegetation $* * 3$ & $\begin{array}{l}\text { Presence of erosion on one margin; } \\
\text { Iguaçu river's arm }\end{array}$ \\
\hline
\end{tabular}

Table 2. Qualitative considered variables among the 15 sampled point's characterization.

\begin{tabular}{cc}
\hline Rank & Rank occurrence among the lakes (\%) \\
\hline RV0 & 6.6 \\
RV1 & 6.6 \\
RV2 & 46.6 \\
RV3 & 40 \\
MF1 & 40 \\
MF2 & 13.3 \\
MF3 & 0 \\
MF & 46.6 \\
Ds1 & 26.6 \\
Ds2 & 66.6 \\
Ds3 & 6.6 \\
\hline
\end{tabular}

Partial Least Square analysis (PLS) was conducted since databases from each sample point, in view of the equitability (J') difference among the lakes. Table 8 presents the variable meaningful and importance for each tested pit.

It is important to know how each variable contributes to the general statistical variance, explaining the involved factors. The productivity in a lentic environment is high when there is the occurrence of high $\mathrm{BOD}_{5}$ and phosphates and nitrates, concomitantly (Esteves 1998, Dodds 2003). Thus, the factor analysis provided that axis $x$ as the environment productivity. PT2, PT5, PT6, PT9, PT11, PT14 and PT15 were related to productivity because they presented the highest values to those variables, as opposed to what happens in other points (Table 3).

Equitability values were higher when the productivity increased (Figure 3), which can be observed by the PLS analysis, that presented high statistical significance in the first and second principal components. The observed eigenvalues were equal in the two principal components $(2,64)$, with an explicability of $24 \%$. It can be explained by $\mathrm{BOD}_{5}$, phosphorous, ortho-phosphate, nitrite, 
Table 3. Physical and chemical parameters of water and the average values among the 15 studied points in July/2009 where $\mathrm{T}\left(\mathrm{H}_{2} \mathrm{O}\right)=$ water temperature; $\mathrm{T}=$ turbidity; $\mathrm{DO}=$ dissolved oxygen; $\mathrm{pH}=$ hydrogenionic potential; $\mathrm{BOD}_{5}=$ biochemistry oxygen demand; $\mathrm{TP}=$ total phosphates; $\mathrm{O}-\mathrm{P}=$ ortho-phosphate; $\mathrm{DOC}=$ dissolved organic carbon; $\mathrm{NO}_{2}^{-}=$nitrite. $\mathrm{NT} / \mathrm{PT}=$ Reason between nitrogen and phosphorous to determinante the limiting fator to the productivity in the 15 sampled lakes.

\begin{tabular}{|c|c|c|c|c|c|c|c|c|c|c|c|}
\hline $\begin{array}{c}\text { Sample } \\
\text { points }\end{array}$ & $\begin{array}{c}\mathrm{T} \\
\left(\mathrm{H}_{2} \mathrm{O}\right)\left({ }^{\circ} \mathrm{C}\right)\end{array}$ & $\begin{array}{c}\text { T } \\
(\mathbf{N T U})\end{array}$ & $\begin{array}{c}\text { OD } \\
(\mathrm{mg} / \mathrm{L})\end{array}$ & pH & $\begin{array}{l}\mathrm{DBO}_{5} \\
(\mathrm{mg} / \mathrm{L})\end{array}$ & $\begin{array}{c}\text { TP } \\
(\mu \mathrm{g} / \mathrm{L})\end{array}$ & $\begin{array}{c}\text { O-P } \\
(\mu \mathrm{g} / \mathrm{L})\end{array}$ & $\begin{array}{c}\text { DOC } \\
(\mathrm{mg} / \mathrm{L})\end{array}$ & $\begin{array}{c}\text { NT } \\
(\mu \mathrm{g} / \mathrm{L})\end{array}$ & $\begin{array}{c}\mathrm{NO}_{2}^{-} \\
(\mu \mathrm{g} / \mathrm{L})\end{array}$ & NT/PT \\
\hline PT1 & 15 & 21.3 & 7.638 & 7.81 & 2.6 & 26.7 & 9.9 & 12.7 & 444.02 & 6.5 & 16,6 \\
\hline PT2 & 15 & 67 & 8.44 & 7.64 & 2.6 & 54.32 & 16.8 & 4.2 & 529.27 & 7.7 & 9,7 \\
\hline PT3 & 15 & 11.8 & 6.4 & 7.65 & 9.4 & 19.9 & 12.3 & 10.5 & 500.85 & 3.8 & 25,2 \\
\hline PT4 & 16 & 16.2 & 4.8 & 6.9 & 6.6 & 24.4 & 9.2 & 4.5 & 292.09 & 3 & 11,9 \\
\hline PT5 & 14.5 & 306 & 7.23 & 7.43 & 4.08 & 135 & 6.8 & 1.8 & 765.17 & 21.1 & 5,7 \\
\hline PT6 & 15 & 20.7 & 8.84 & 7.58 & 13.44 & 29.1 & 17.7 & 3.1 & 410.26 & 2.9 & 14,1 \\
\hline PT7 & 15 & 133 & 6.43 & 7.44 & 4 & 57.8 & 41.6 & 1.8 & 571.58 & 6.1 & 9,9 \\
\hline PT8 & 15 & 17.6 & 10.05 & 7.18 & 2.6 & 56.5 & 14.3 & 2.7 & 104.32 & 6.6 & 1,8 \\
\hline PT9 & 15 & 26.5 & 8.44 & 7.57 & 2.7 & 40.3 & 14.6 & 4 & 418.38 & 7.8 & 10,4 \\
\hline PT10 & 16 & 22.5 & 7.63 & 7.62 & 6.8 & 28.9 & 8.8 & 2.7 & 260.47 & 7 & 9,0 \\
\hline PT11 & 16 & 47.8 & 6.43 & 7.55 & 2.7 & 39.2 & 22.2 & 3.1 & 348.29 & 4.3 & 8,9 \\
\hline PT12 & 15 & 97.7 & 8.44 & 7.93 & 1.4 & 75.3 & 33.4 & 4 & 725.39 & 6.3 & 9,6 \\
\hline PT13 & 16 & 38.2 & 2.01 & 7.2 & 14.7 & 252 & 92.2 & 6.6 & 6252.1 & 67.8 & 24,8 \\
\hline PT14 & 15.5 & 46.2 & 1.201 & 6.94 & 28.1 & 165 & 62.4 & 7.6 & 966.08 & 4.9 & 5,8 \\
\hline PT15 & 15.5 & 117 & 4.02 & 6.86 & 14.8 & 85.8 & 17.7 & 3.6 & 1175.2 & 4.9 & 13,7 \\
\hline Mean & 15.3 & 66.0 & 6.5 & 7.4 & 7.8 & 72.7 & 25.3 & 4.9 & 917.6 & 10.7 & \\
\hline SD & 0.5 & 76.7 & 2.5 & 0.3 & 7.3 & 64.8 & 23.7 & 3.2 & 1501.7 & 16.4 & \\
\hline IC -95\% & 15.03 & 23.47 & 5.13 & 7.24 & 3.72 & 36.80 & 12.17 & 3.10 & 85,97 & 1.65 & \\
\hline IC +95\% & 15.57 & 108.47 & 7.93 & 7.60 & 11.81 & 108.56 & 38.48 & 6.62 & 1749,16 & 19.78 & \\
\hline
\end{tabular}

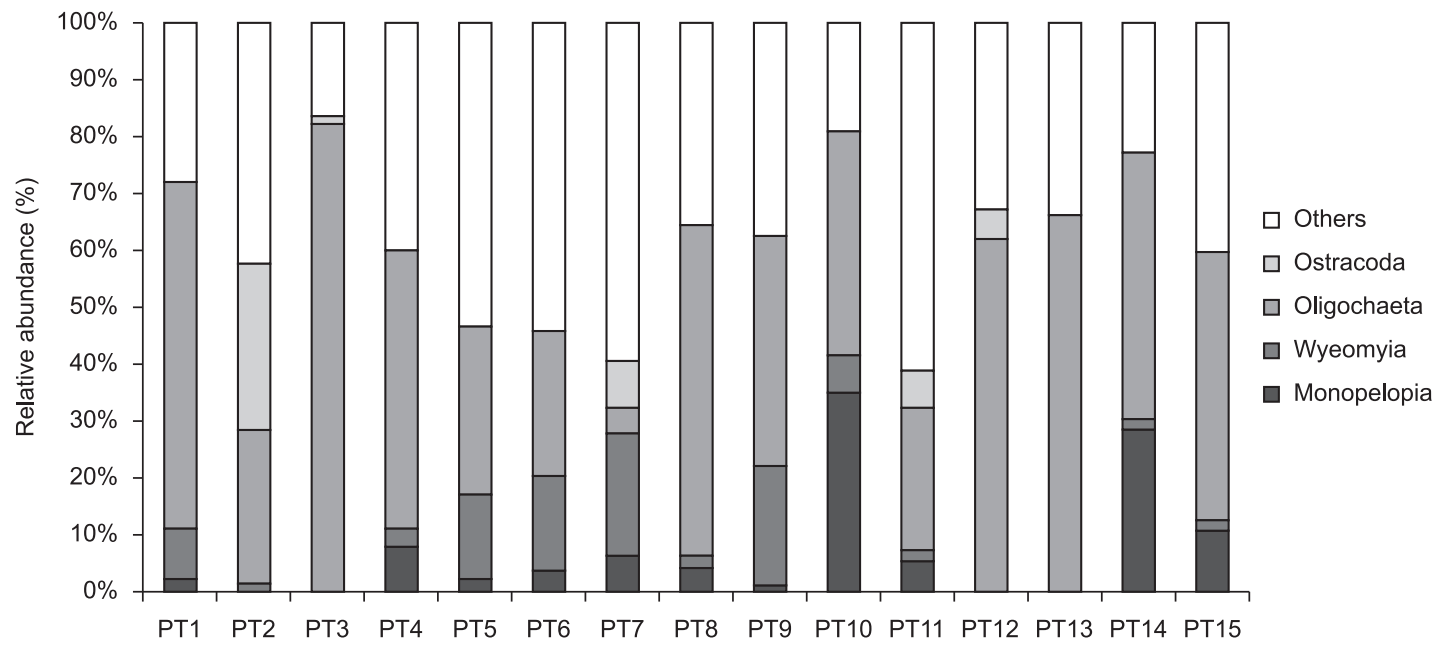

Figure 2. Taxa with more than $5 \%$ of abundance and occurrence in more than three sampled points.

and abundant ciliar vegetation grouping, opposed to $\mathrm{DO}$ and $\mathrm{pH}$. DO and COD were influent variables, as well as dense ciliar vegetation.

Chironomidae, Oligochaeta and Ostracoda had the higher relative abundances. Due to this importance, the PLS was conducted to these taxa as dependent variables, and as well as equitability response, the productivity was the explicative factor (Figures 4, 5 and 6). The most influent variables are ranked in Table 4.

The realized analyses to Chironomidae and Ostracoda did not present statistical significance to the two first components, so, we assumed to analyze only the first principal component. The eigenvalue to Chironomidae was 2,93 , assuming an explicability of only $24 \%$. To Ostracoda the eigenvalue to the first component was 2,93, with an explicability of $25 \%$. Thus, this analysis demonstrated a low explicability to Chironomidae and Ostracoda. It is noteworthy that the lakes with higher macrophytes' frequency (51-75\% and 76-100\%) had higher representativeness and, because of this, had higher explicability power. The analysis on Ostracoda was significant to 
Aquatic Invertebrate's community in lakes from the Alto Iguaçu

Table 4. Total entomofauna's observed frequency (TEF) among the 15 sampled lakes.

\begin{tabular}{|c|c|c|c|c|c|}
\hline Taxa & Genus & TEF (\%) & Taxa & Genus & TEF (\%) \\
\hline Ephemeroptera & & & Mesoveliidae & Mesovellia & 13 \\
\hline Ephemeroptera & & 13 & Naucoridae & Pelocoris & 7 \\
\hline Baetidae & Apobaetis & 27 & Notonectidae & Notonecta & 27 \\
\hline Caenidae & Caenis & 60 & Pleidae & Paraplea & 20 \\
\hline Leptohyphydae & Tricorythopsis & 7 & Lepidoptera & & \\
\hline Leptohyphydae & Traveryphes & 7 & Noctuidae & & 13 \\
\hline Leptohyphydae & Leptohyphodes & 20 & Pyralidae & Crambus & 27 \\
\hline Leptophlebiidae & Traverella & 13 & Trichoptera & & \\
\hline Odonata & & & Hydroptilidae & Neotrichia & 20 \\
\hline Aeshnidae & Castoaeschna & 20 & Polycentropodidae & Cyrnellus & 7 \\
\hline Aeshnidae & Coryphaesna & 7 & Coleoptera & & \\
\hline Aeshnidae & Limnetron & 7 & Chrysomelidae & Disonycha & 7 \\
\hline Coenagrionidae & Ischnura & 7 & Curculionidae & & 27 \\
\hline Coenagrionidae & Oxyagrion & 20 & Curculionidae & Listronotus & 7 \\
\hline Coenagrionidae & Telebasis & 100 & Curculionidae & Lixus & 27 \\
\hline Dicteriadidae & Eleocharis & 7 & Dytiscidae & Acilius & 20 \\
\hline Lestidae & Lestes & 20 & Dytiscidae & Hygrospus & 20 \\
\hline Libellulidae & Erythrodiplax & 73 & Elmidae & & 7 \\
\hline Libellulidae & Brechmorhoga & 67 & Elmidae & Hexanchorus & 13 \\
\hline Perilestidae & Perilestes & 7 & Haliplidae & Haliplus & 13 \\
\hline Protoneuridae & Epipleoneura & 7 & Hydrophilidae & & 7 \\
\hline Protoneuridae & Neoneura & 13 & Hydrophilidae & Berosus & 7 \\
\hline Heteroptera & & & Hydrophilidae & Dibolocelus & 40 \\
\hline Belostomatomatidae & Belostoma & 27 & Hydrophilidae & Helobata & 87 \\
\hline Corixidae & Cymatia & 27 & Lampyridae & & 60 \\
\hline Corixidae & Tenaglobia & 33 & Melolonthidae & & 13 \\
\hline Hebridae & Hebrus & 13 & Noteridae & Hydrocanthus & 13 \\
\hline Taxa & Subfamily/Genus & TEF (\%) & Taxa & Subfamily/Genus & TEF (\%) \\
\hline Noteridae & Pronoterus & 7 & Chironomidae & Caladomyia & 27 \\
\hline Scirtidae & Microcara & 40 & Chironomidae & Chironomus & 27 \\
\hline Staphilinidae & Pontamalota & 7 & Chironomidae & Cryptochironomus & 7 \\
\hline Diptera & & & Chironomidae & Dicrotendipes & 7 \\
\hline Muscidae & & 7 & Chironomidae & Harnischia & 13 \\
\hline Ceratopogonidae & Dasyhelea & 27 & Chironomidae & Parachironomus & 33 \\
\hline Ceratopogonidae & Probezzia & 80 & Chironomidae & Polypedilum & 27 \\
\hline Ceratopogonidae & Stilobezzia & 33 & Chironomidae & Rheotanytarsus & 7 \\
\hline Chaoboridae & Chaoborus & 7 & Chironomidae & Tanytarsus & 27 \\
\hline Culicidae & Aedes & 13 & Chironomidae & Tanytarsini gen $A$ & 20 \\
\hline Culicidae & Anopheles & 27 & Chironomidae & Orthocladiinae & 53 \\
\hline Culicidae & Culiseta & 7 & Chironomidae & Corynoneura & 7 \\
\hline Culicidae & Mansonia & 7 & Chironomidae & Cricotopus & 7 \\
\hline Culicidae & Toxorhynchites & 7 & Chironomidae & Parametriocnemus & 13 \\
\hline Culicidae & Wyeomyia & 87 & Chironomidae & Tanypodinae & 80 \\
\hline Dixidae & Dixa & 7 & Chironomidae & Procladini & 7 \\
\hline Empididae & & 20 & Chironomidae & Djalmabatista & 13 \\
\hline Ephydridae & & 7 & Chironomidae & Ablabesmyia & 53 \\
\hline Sciomyzidae & Tetanocera & 13 & Chironomidae & Clinotanypus & 7 \\
\hline Stratiomidae & Euparyphus & 53 & Chironomidae & Coelotanypus & 27 \\
\hline Stratiomidae & Mixosargus & 7 & Chironomidae & Labrundinia & 73 \\
\hline Syrphidae & & 7 & Chironomidae & Larsia & 67 \\
\hline Tabanidae & Chrysops & 73 & Chironomidae & Monopelopia & 73 \\
\hline Tipulidae & & 20 & Chironomidae & Pentaneura & 20 \\
\hline Chironomidae & Chironominae & & Chironomidae & Tanypus & 20 \\
\hline Chironomidae & Aedokritus & 27 & Chironomidae & Thienemannimyia & 53 \\
\hline Chironomidae & Beardius & 7 & Chironomidae & Zavrelimyia & 13 \\
\hline
\end{tabular}


Table 5. Total macroinvertebrates' observed frequency (TF) except insects among the 15 sampled lakes.

\begin{tabular}{llc}
\hline \multicolumn{1}{c}{ Taxa } & \multicolumn{1}{c}{ Genus } & TF (\%) \\
\hline Oligochaeta & & 100 \\
Hirudinea & & 87 \\
Glossiphoniidae & & 0 \\
Bivalvia & & 27 \\
Platyhelmintes & & 13 \\
Nematoda & & 7 \\
Mollusca & Anodontites & 7 \\
Mollusca Mycetopodidae & Pomacea & 7 \\
Mollusca Ampullariidae & Physa & 27 \\
Mollusca Physidae & Biomphalaria & 60 \\
Mollusca Planorbidae & Drepanotrema & 7 \\
Mollusca Planorbidae & & 7 \\
Mollusca Gastropoda & 7 \\
$\quad$ Mollusca Gastropoda Ampullariidae & 13 \\
$\quad$ Mollusca Gastropoda Ancylidae & & 7 \\
Hydracarina & & 40 \\
Cladocera & & 87 \\
Copepoda & & 20 \\
Crustacea Isopoda & & 13 \\
Amphipoda & & 7 \\
Isopoda & & 13 \\
Crustacea Decapoda & & \\
Ostracoda & & \\
Collembola & & \\
\hline & & \\
\hline
\end{tabular}

Table 6. Macrofauna attributes in Alto Iguaçu pits, where $\mathrm{S}=$ taxonomic richness; $\mathrm{N}=$ total abundance; $\mathrm{D}=$ dominance; $\mathrm{d}=$ Margalef richness index, and $\mathrm{J}^{\prime}=$ equitability.

\begin{tabular}{cccccc}
\hline Sample points & S & N & D & d & J' \\
\hline PT1 & 46 & 666 & 0.39 & 6.92 & 0.47 \\
PT2 & 21 & 116 & 0.19 & 4.21 & 0.68 \\
PT3 & 24 & 342 & 0.67 & 3.94 & 0.31 \\
PT4 & 50 & 1429 & 0.26 & 6.74 & 0.55 \\
PT5 & 32 & 553 & 0.15 & 4.91 & 0.67 \\
PT6 & 42 & 622 & 0.14 & 6.37 & 0.65 \\
PT7 & 20 & 160 & 0.12 & 3.74 & 0.80 \\
PT8 & 24 & 242 & 0.36 & 4.19 & 0.55 \\
PT9 & 43 & 527 & 0.21 & 6.70 & 0.61 \\
PT10 & 33 & 608 & 0.28 & 4.99 & 0.52 \\
PT11 & 32 & 259 & 0.11 & 5.58 & 0.77 \\
PT12 & 16 & 55 & 0.39 & 3.74 & 0.60 \\
PT13 & 22 & 438 & 0.46 & 3.45 & 0.42 \\
PT14 & 53 & 1442 & 0.30 & 7.15 & 0.46 \\
PT15 & 58 & 881 & 0.24 & 8.40 & 0.58 \\
\hline
\end{tabular}

Table 7. Descriptive statistics to the ecological indexes.

\begin{tabular}{cccccc}
\hline & Mean & $\begin{array}{c}\text { Confidence } \\
\mathbf{- 9 5 , 0 0 0 \%}\end{array}$ & $\begin{array}{c}\text { Confidence } \\
\mathbf{+ 9 5 , 0 0 0 \%}\end{array}$ & Variance & Std.Dev. \\
\hline S & 34.4 & 27.0 & 41.8 & 180.1 & 13.4 \\
N & 556 & 321 & 791 & 180050.1 & 424.3 \\
Dm & 0.3 & 0.2 & 0.4 & 0.0 & 0.2 \\
d & 5.4 & 4.5 & 6.3 & 2.4 & 1.5 \\
J' & 0.6 & 0.5 & 0.6 & 0.0 & 0.1 \\
\hline
\end{tabular}

the two first components, presenting eigenvalues of 3,41 and 1,70, respectively.

In all the done analysis was possible to observe that the first principal component defined the data variability depending on the trophic level. In lakes with low $\mathrm{pH}, \mathrm{OD}$ and reduced macrophytes' frequency we understood as low productivity, indicating low trophic level.

There were not environments with good or excellent water quality according to the BMWP'. The most sample points were classified in acceptable or questionable, while the PT2 was classified in very critical water quality (Table 9).

The Plecoptera Order was absent in all sample points. Trichoptera was rare in PT2, PT3, PT6 and PT10 $(n=1)$ as well in PT4 $(n=6)$. Ephemeroptera was not sampled in PT1, PT11, PT13 and PT14, occurring in all others (always with less than $2 \%$ of contribution to the community). On the other hand, Chironomidae was sampled in all sample points. All the sample points showed a reason smaller than one to this metric, evidencing a commitment of water quality (Table 9).

\section{Discussion}

The Monopelopia sp. abundance can be related to macrophyte abundance, due to this taxon morphological adaptation to colonize these aquatic plants, as registered by Armitage et al. (1995). Peiró \& Alvez (2006) related all the macroinvertebrates community from the Ribeirão das Anhumas dam's littoral region with macrophytes disposition, considering the food supply and shelter as advantages to the occurrence. Indeed, the organisms' richness was very represented by the detected portion of aquatic plants. The vegetation in shoreline favors the littoral zone, especially in lentic environments, because they provide a diverse habitat, increasing the richness, and other ecological indexes (Ward 1992, Corgosinho et al. 2004).

Assireu et al. (2009) suggest that higher margin development index, greater the aquatic community establishment probability and greater the catchment interference. Our study has not confirmed this pattern, because the index was not explicative factor nor even to community structure or to the three more dominants taxa (Chironomidae, Oligochaeta and Ostracoda). So, this variable was excluded from analysis, as well macrophytes and the altitude.

In spite of macrophytes exclusion from analysis, the highest equitability values were observed in those points with more than $30 \%$ of water surface covered by them. The reduced macrophyte presence in some points permitted to note the association between macrophytes and complex riparian vegetation. However, elevated quironomid and oligochaete density were found in lakes with all water surface covered by aquatic plants and complex riparian vegetation surrounding. This emphasizes the macrophytes and riparian vegetation association as an important ecological role to macroinvertebrate's community.

Weatherhead \& James (2001) verified that depth, turbidity and flood peaks were not influent factors on the macroinvertebrate's abundance and distribution; however the suspended solids modified the macrophytes. Macrophytes are related to nutrients supply, even in oligotrophic lakes (Weathehead \& James 2001), to egg deposition and refuge to these animals, besides to be an important factor to habitat heterogeneity (Jackson 1997, Higuti \& Takeda 2002). Macrophytes architectonic types have explained the abundance variation of macrofauna in lakes (Cheruvelil et al. 2000), besides to support the distribution pattern. In shallow ecosystems these plants assume a more relevant ecological role, since they can colonize all the environments and increase the primary production rate (Cervi et al. 2009).

The observed macrophyte quantity and riparian vegetation density permit to infer that the two parameters together increase the shading on the water body, as consequence, take to lower productivity in water, 
Aquatic Invertebrate's community in lakes from the Alto Iguaçu

Table 8. Partial Least Square (PLS) results to the 15 Alto Iguaçu lake's attributes community for the most explicative factors to taxa equitability (J') and abundance (Chironomidae, Oligachaeta e Ostracoda). The highlighted factors are the three first ones in relation to importance, pointed by the analysis.

\begin{tabular}{|c|c|c|c|c|c|c|c|c|}
\hline \multirow{2}{*}{ Variables } & \multicolumn{2}{|c|}{$\mathrm{J}$ ' } & \multicolumn{2}{|c|}{ Chironomidae } & \multicolumn{2}{|c|}{ Oligochaeta } & \multicolumn{2}{|c|}{ Ostracoda } \\
\hline & Pw & Imp & $\mathbf{P w}$ & Imp & Pw & Imp & Pw & Imp \\
\hline $\mathrm{T}\left(\mathrm{H}_{2} \mathrm{O}\right)\left({ }^{\circ} \mathrm{C}\right)$ & $*$ & * & $*$ & * & 0.44 & 10 & 0.13 & 9 \\
\hline Turbidity & * & * & * & * & 0.17 & 12 & 0.001 & 12 \\
\hline DO (mg/L) & 0.81 & 1 & 0.77 & 2 & 0.79 & 1 & 0.68 & 2 \\
\hline pH & 0.52 & 7 & 0.78 & 1 & 0.62 & 4 & 0.33 & 7 \\
\hline BOD $_{5}$ & 0.61 & 6 & 0.7 & 3 & 0.57 & 6 & 0.5 & 5 \\
\hline Total Phosphate (mg/L) & 0.7 & 4 & 0.31 & 6 & 0.74 & 2 & 0.76 & 1 \\
\hline Ortho-phosphate (mg/L) & 0.66 & 5 & 0.29 & 7 & 0.74 & 3 & 0.65 & 3 \\
\hline DOC (mg/L) & 0.77 & 2 & 0.01 & 11 & 0.18 & 11 & 0.07 & 10 \\
\hline Nitrite (mg/L) & 0.36 & 10 & 0.05 & 9 & 0.59 & 5 & 0.52 & 4 \\
\hline $\mathrm{CV}$ & 0.72 & 3 & 0.01 & 10 & 0.08 & 13 & & \\
\hline$R^{2}$ of $x$ & \multicolumn{2}{|c|}{0.3} & \multicolumn{2}{|c|}{0.34} & \multicolumn{2}{|c|}{0.32} & \multicolumn{2}{|c|}{0.33} \\
\hline$p$ & \multicolumn{2}{|c|}{$<0.05$} & \multicolumn{2}{|c|}{$>0.05$} & \multicolumn{2}{|c|}{$<0.05$} & \multicolumn{2}{|c|}{$>0.05$} \\
\hline Variance (\%) & \multicolumn{2}{|c|}{85} & \multicolumn{2}{|c|}{81} & \multicolumn{2}{|c|}{96} & \multicolumn{2}{|c|}{38} \\
\hline
\end{tabular}

$\mathrm{Pw}=$ Power (analysis influence). Imp = Importance (relevant rank).

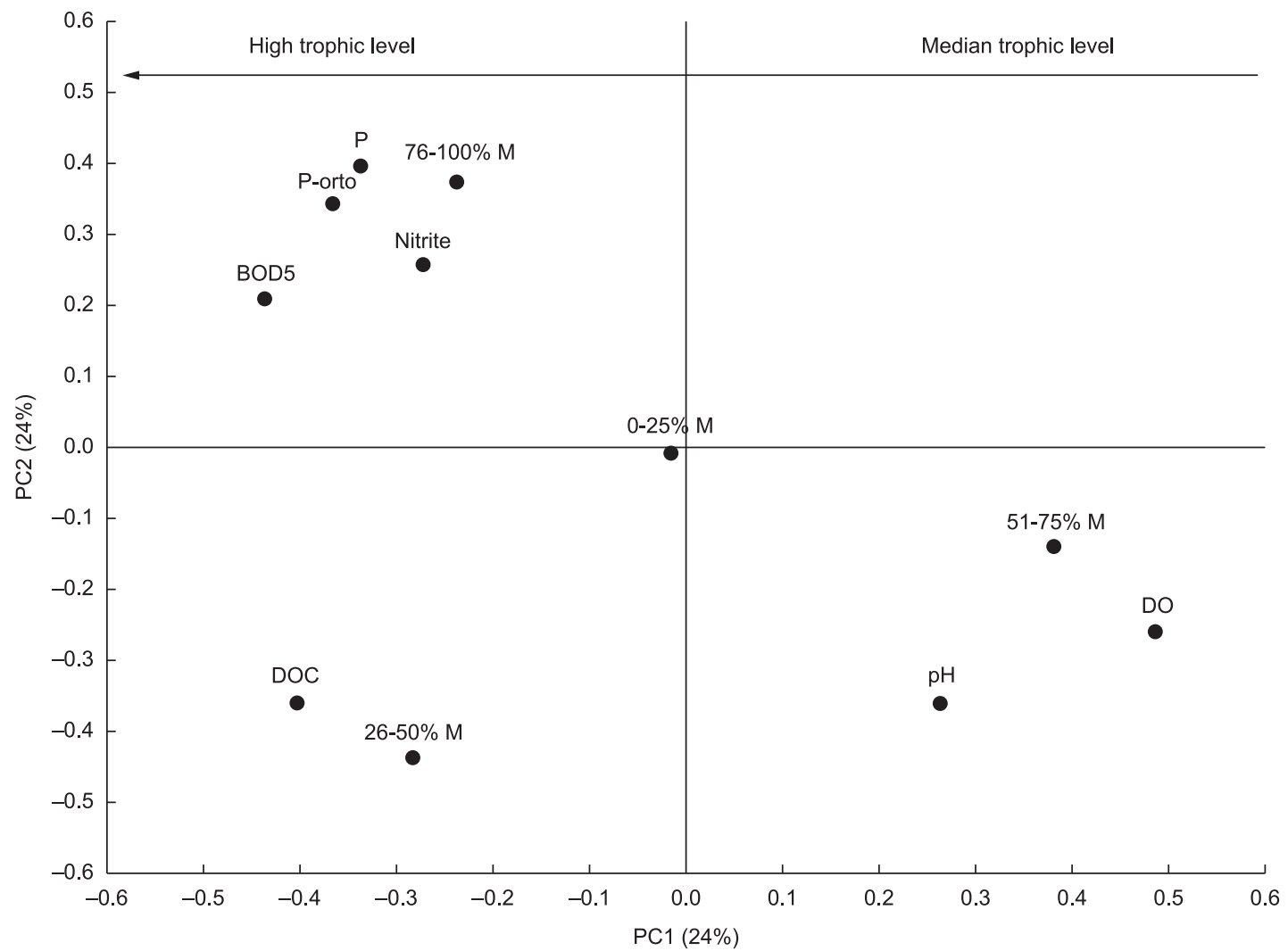

Figure 3. PLS analysis indicating observed variables weight on components 1 and 2, and its relationships to macroinvertebrates equitability distribution among the points.

but in the other hand keep constant temperature and inhibit algae bloom (Silans 2003). In natural non-eutrophic lakes, the vegetation and shallowness are more efficient in phosphorous conversion to biomass disposed to phytoplankton, even the primary production is constant (Nixdorf \& Deneke 1997).
Dissolved oxygen is one of the most important variables in limnological characterization due to its chemical reaction participation in water (Tundisi \& Matsumura-Tundisi 2008), and it can be controlled by macrophytes in as much as they metabolize 16 to $34 \%$ of Total Phospates and nitrogen in a lacustrine system (Carpenter 


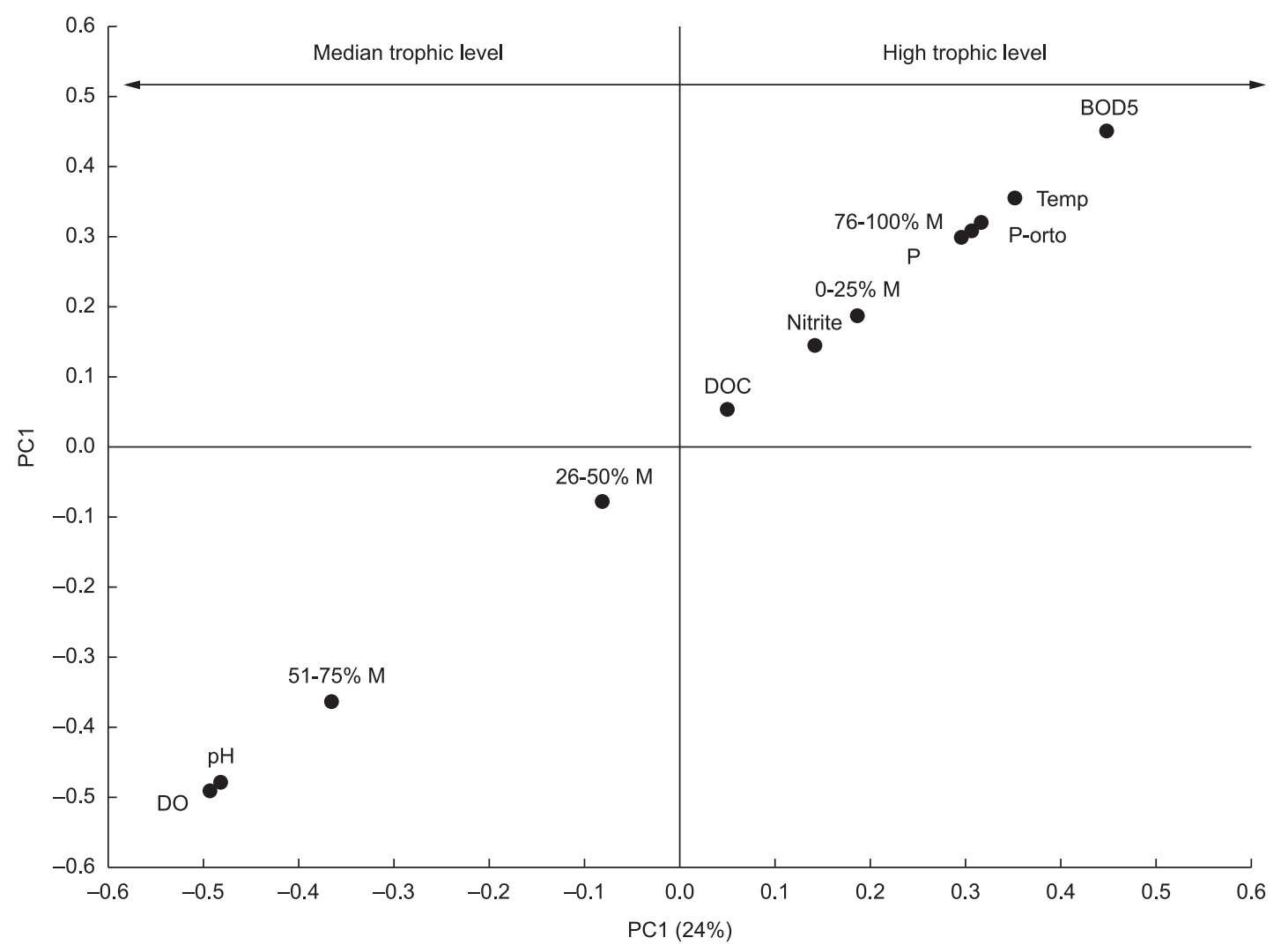

Figure 4. PLS analysis indicating observed variables weight on components 1 and 2, and its relationships to Chironomidae dominance.

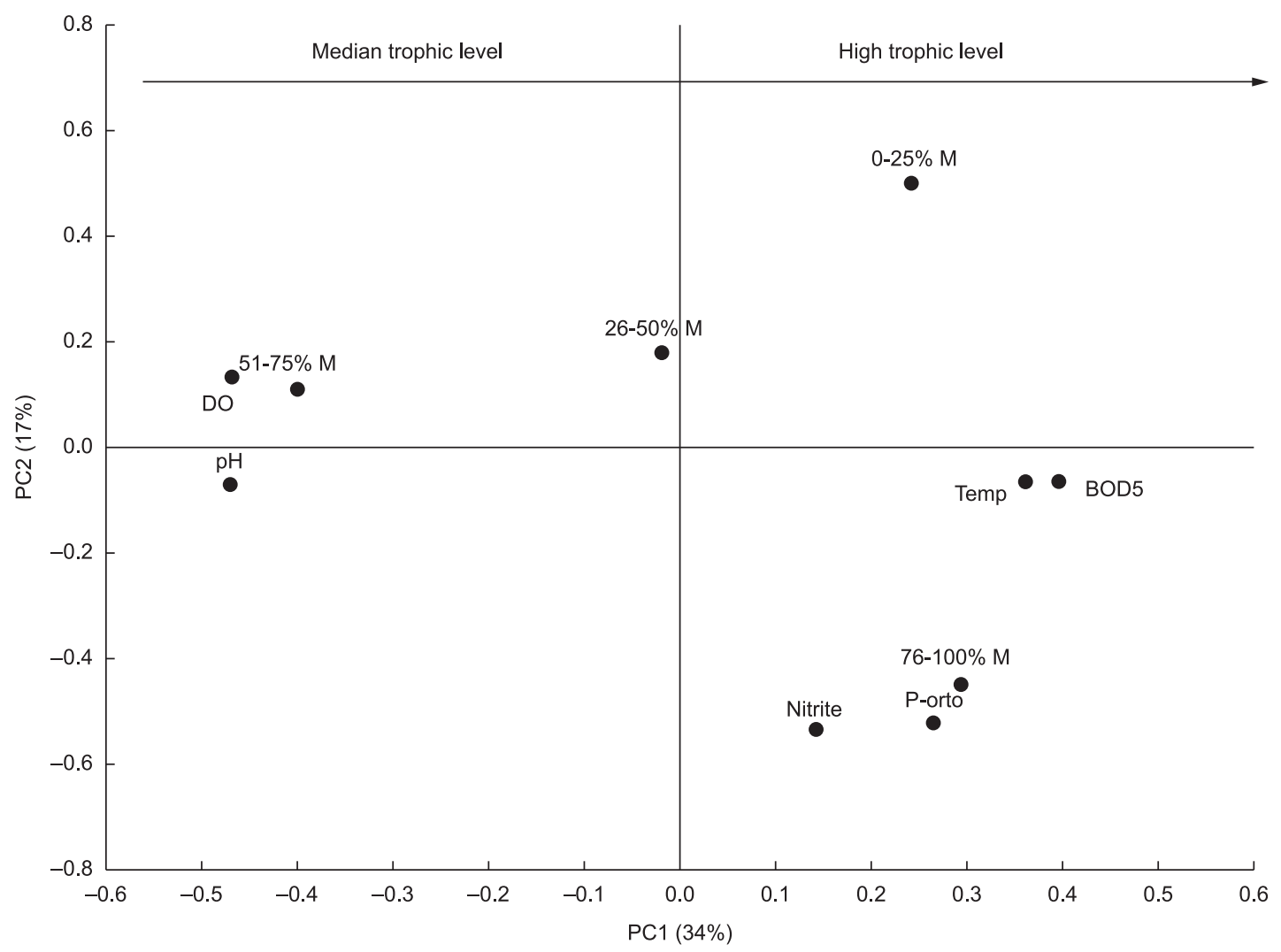

Figure 5. PLS analysis indicating observed variables weight on components 1 and 2, and its relationships to Oligochaeta dominance. 


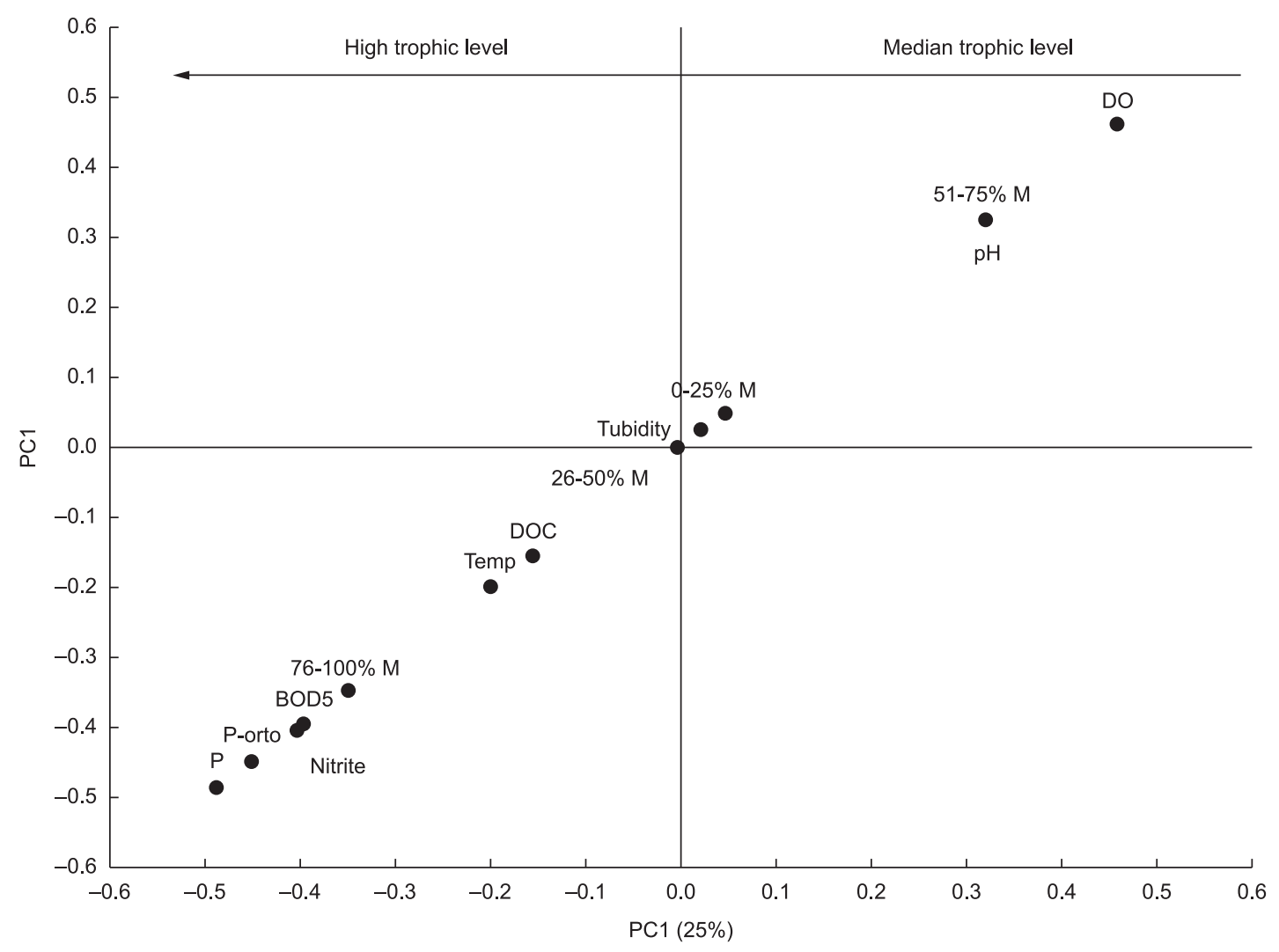

Figure 6. PLS analysis indicating observed variables weight on components 1 and 2, and its relationships to Ostracoda dominance.

Table 9. Biological indexes values to water quality in the 15 sample points from the Alto Iguaçu region. EPT/C = reason between the proportion of Ephemeroptera, Plecoptera and Trichoptera taxa in relation to Chironomidae. BMWP'= Biological Monitoring Work Party System, where acceptable water quality $=$ moderated evidences of pollution; Doubtful $=$ polluted waters (alterated systems), and Critical $=$ much polluted waters (very alterated systems).

\begin{tabular}{lccl}
\hline Sample points & EPT/C & BMWP' & \\
\hline PT1 & Value & Value & \multicolumn{1}{c}{ Quality } \\
PT2 & 0,014 & 78 & Acceptable \\
PT3 & 0,2 & 31 & Critical \\
PT4 & 0,198 & 62 & Acceptable \\
PT5 & 0,044 & 48 & Acceptable \\
PT6 & 0,071 & 65 & Doubtful \\
PT7 & 0,142 & 46 & Acceptable \\
PT8 & 0,017 & 31 & Doubtful \\
PT9 & 0,03 & 77 & Acceptable \\
PT10 & 0,02 & 57 & Doubtful \\
PT11 & 0 & 54 & Doubtful \\
PT12 & 0,5 & 27 & Critical \\
PT13 & 0 & 48 & Doubtful \\
PT14 & 0 & 85 & Acceptable \\
PT15 & 0,077 & 95 & Acceptable \\
\hline
\end{tabular}

\& Adams 1977), increases the exponential growth rate, which one provides oxidation and limits the radiation to biota because releases phosphorous, and consequently, suspended solids (Thiébaut 2008). Wetzel (1984) assumes that aquatic macrophytes can act increasing or reducing DOC. In this study, we observed that, lowest macrophyte distribution on water surface, conducted to higher DOC rate (PT1 and PT3), while highest presence of this plant on water, indicated lowest DOC.

Profundal zones tend to homogeneity and oxygen depletion, especially in stratified lakes. Still the littoral zone presents more spatial heterogeneity, favoring biomass accumulation and greater diversity. It makes the littoral zone to fluctuate more, requiring population adaptations and fluctuations in reduced time (Tundisi \& Matsumura-Tundisi 2008).

Several studies show the relationship among productivity and phosphorous and nitrogen availability, indicating the phosphorous as limiting nutrient to this process (Schilling \& Lockaby 2006). Brauns et al. (2007) observed that while a community part was related to organic matter and conductivity reduction, there was another positively related to phosphorous. For these authors, the relation with phosphorous infers about productivity and, therefore, the macroinvertebrate's composition was associated to system productivity. Lenat \& Rawford (1994) show that macroinvertebrates abundance increases according to productivity in agricultural streams. It is expected that the macroinvertebrate's community variability be great as more complex is the habitat, permitting a wild niche (Heino 2000, Harrison \& Hildrew 2001).

The dominance displayed by Chironomidae and Oligochaeta is common (Bazzanti et al. 2000, Abílio et al. 2005) including its relationship to eutrophic environments (Buckup et al. 2007, 
O'Toole et al. 2008), since they are organisms with a wild plasticity about available resources. Besides, another relevant factor are these two groups biological features, like respiratory pigment (hemoglobin) and body movement that optimizes the oxygen catchment from environment (Higuti \& Takeda 2002), even in very depleted concentrations. According to Fuller \& Cowell (1985) the quironomids larvae are r-strategists and inhabit areas with a very variable conditions range, what justifies their advantage among the lake's analyses.

Investigations about oligochaete's abundance indicate higher values of this taxon in lentic samples, especially in profundal zones (sediment) (Milbrink et al. 2002), also occurring relationship between the oligochaete's abundance in accordance of organic pollution (Lang 1997, 1998). Corbi (2001) found that in oligotrophic reservoirs the benthic fauna was composed of fewer than $20 \%$ oligochaetes, whereas Pamplin (1999) registered a fauna composition of $73 \%$ by oligochaetes in hypertrophic lentic habitats.

The taxonomic diversity shows sensibility when the communities are exposed to habitat alterations or to any environmental stress (Andrade 2009) like the ones in water quality. Among the analyzed lakes, there were sample points classified as acceptable, to water quality through the BMWP' index (PT4 and PT15), which also had the highest values to diversity index. According to Barbosa et al. (2001) the presence of some groups like Baetidae, Odonata, Ephemeroptera and Trichoptera is associated to macrophytes, so this community reflects an elevated nutrients availability, and as already mentioned, the Chironomidae dominance is, many times, associated to environmental degradation (Fuller \& Cowell 1985), the own BMWP's score is very low (1). Thus, the dataset presented here, be the comparisons between the structure and community composition, be the association of those with the physical and chemical water characteristics or the water evaluation through saprobiotic index, show that, these lakes, although the invertebrates colonization occurs, have low degree of environmental integrity, selecting, this way, the taxonomic groups found in each sample point.

\section{Conclusions}

The lakes presented different environmental conditions, and especially about chemical variables, the variance was conducted according to the connection to Iguaçu River's channel, besides the macrophytes presence. The variable set was explained by the ecosystem productivity. This factor was strongly influent on distribution of macroinvertebrates community, even if we had not significance difference among ecological indexes.

\section{References}

ABÍLIO, F.J.P., FONSECA-GESSNER, A.A.F., WATANABE, T. \& LEITE, R.L. 2005. Fauna de Chironomidae e outros insetos aquáticos de açudes do semi-árido paraibano, Brasil. Entomol. Vect. 12(2):255-264. http:// dx.doi.org/10.1590/S0328-03812005000200009

ALBERTONI, E.F., PRELLVITZ, L.J. \& PALMA-SILVA, C. 2007. Macroinvertebrates fauna associated with Pistia stratiotes and Nymphoides indica in subtropical lakes (south Brazil). Braz. J. Biol. 67(3):499-507. http://dx.doi.org/10.1590/S1519-69842007000300015

ALVES, E., CARDOSO, L.R., SAVRONI, J., FERREIRA, L.C., BOARO, C.S.F. \& CATANEO, A.C. 2003. Physiological and biochemical evaluations of water hyacinth (Eichhornia crassipes), cultivated with excessive nutrient levels. Planta Daninha 21:27-35.

ANDRADE, C.C. 2009. Macroinvertebrados bentônicos e fatores físicos e químicos como indicadores de qualidade de água da bacia do Alto Jacaré-Guaçu (SP). Dissertação de Mestrado, Universidade Federal de São Carlos, São Carlos, 75p.
AMERICAN PUBLIC HEALTH ASSOCIATION - APHA, AMERICAN WATER WORKS ASSOCIATION - AWWA, WATER ENVIRONMENT FEDERATION - WEF. 2005. Standard methods for examination of water and waste water. 21st ed. APHA, Washington.

ARMitAGE, P.D., CRANSTON, P.S. \& PINDER, L.C.V. 1995. The Chironomidae: biology and ecology of non-biting midges. Chapman and Hall, London.

ASSIREU, A.T., FREITAS, R.M., NOVO, E.M.L.M., PACHECO, F.S. \& STECH, J.L. 2009. Índice de criticalidade da qualidade da água em lagos e reservatórios: Uma proposta de metodologia baseada em variáveis estáticas e dinâmicas. In XIV Simpósio Brasileiro de Sensoriamento Remoto. Natal, p.4639-4646.

BARBOSA, F.A.R., CALLISTO, M. \& GALDEAN, N. 2001. The diversity of benthic macroinvertebrates as an indicator of water quality ande cosystem health: a case study for Brazil. Aquat. Eco. Health and Manag. Soc. 4:51-59. http://dx.doi.org/10.1080/146349801753569270

BAZZANTI, M., SEMINARA, M., BALDONI, S. \& STELLA, A. 2000. Macroinvertebrates and Environmental Factors of Some Temporary and Permanent ponds in Italy. Verh. Internat. Limnol. 27:936-941.

BERG, M.V.D.M., COOPS, H., NOORDHUIS, R., SCHIE, J.V. \& SIMONS, J. 1997. Macroinvertebrate communities in relation to submerged vegetation in two Chara-dominated lakes. Hydrobiol. 342(343):143-150. http://dx.doi.org/10.1023/A:1017094013491

BIGGS, B.J.F. \& MALTHUS, T.J. 1982. Macroinvertebrates associated with various aquatic macrophytes in the backwaters and lakes of the upper Clutha Valley, New Zealand, NZ. J. Mar. and Freshw. Res. 16:81-88. http://dx.doi.org/10.1080/00288330.1982.9515948

BONADA, N., PRAT, N., RESH, V.H. \& STATZNER, B. 2006. Developments in aquatic insect biomonitoring: a comparative analysis of recent approaches. An. Rev. Entomol. 51:495-523. http://dx.doi.org/10.1146/ annurev.ento.51.110104.151124

BOTTS, P.S. \& COWELL, B.C. 1993. Temporal Patterns of Abundance of Epiphytic Invertebrates on Typha Shoots in a Subtropical Lake. J. N. Am. Benthol. Soc. 12(1):27-39. http://dx.doi.org/10.2307/1467682

BRAUNS, M., GARCIA, XF., PUSCH., MT. \& WALZ, N. 2007. Eullitoral macroinvertebrate communities of lowland lakes: discrimination among trophic states. Freshw. Biol. 52:1022-1032. http://dx.doi.org/10.1111/ j.1365-2427.2007.01750.x

BUCKUP, L., BUENO, A.A.P., BOND-BUCKUP, G., CASAGRANDE, M. \& MAJOLO, F. 2007. The Benthic Macroinvertebrate Fauna of Highland Streams in Southern Brazil: Composition, Diversity and Structure. Bras. J. Biol. 24(2):294-301.

CALLISTO, M.; BARBOSA, F.A.R. \& MORENO, P. 2000. Macrobenthic diversity on different habitats in an altitudinal lake surrounded by Eucalyptus plantations and secondary Atlantic Forest (southeast Brazil). Acta Limnol. Brasil. 12:55-61.

CARIGNAN, R.E. \& NEIFF, J.J. 1992. Nutrient dynamics in the floodplain ponds of the Paraná River (Argentina) dominated by Eichhornia crassipes. Biogeochemistry 17:85-121. http://dx.doi.org/10.1007/BF00002642

CARPENTER, S.R. \& ADAMS, M.S. 1977. The macrophyte tissue nutrient pool for a hardwater eutrophic lake: implication for macrophyte harvesting. Aquat. Bot. 3:239-255. http://dx.doi.org/10.1016/03043770(77)90026-2

CARRASCAL, L.M., GALVÁN, I. \& GORDO, O. 2009. Partial least squares regression as an alternative to current regression methods used in ecology. Oikos 118:681-690. http://dx.doi.org/10.1111/j.1600-0706.2008.16881.x

CERVI, A.C., BONA, C., MOÇO, M.C.C. \& VON LINSINGEN, L. 2009. Macrófitas aquáticas do município de General Carneiro. Paraná, Brasil. Biota Neotrop. 9(3):215-222. http://dx.doi.org/10.1590/S167606032009000300022

CHANDRA, S., VANDER ZANDEN, M.J., HEYVAERT, A.C., RICHARDS, B.C., ALLEN, B.C. \& GOLDMAN, C.R. 2005. The effects of cultural eutrophication on the coupling between pelagic primary producers and benthic consumers. Limnol. Oceanogr. 50:1368-1376. http://dx.doi. org/10.4319/lo.2005.50.5.1368 
CHERUVELIL, K.S., SORANNO, P.A. \& SERBIN, R.D. 2000 Macroinvertebrates associated with submerged macrophytes: sample size and power to detect effects. Hydrobiol. 441:133-139. http://dx.doi. org/10.1023/A:1017514824711

CORBI, J.J. 2001. Distribuição espacial e batimétrica dos macroinvertebrados bentônicos da represa do Ribeirão das Anhumas (Américo Brasiliense SP). Dissertação de Mestrado, Universidade Federal de São Carlos, São Carlos.

CORGOSINHO, P.H.C., CALIXTO, L.S.F., FERnANDES, P.L., GAGLIARDI, L.M. \& BALSAMÃO, V.L.P. 2004. Diversidade de habitats e padrões de diversidade e abundância do bentos ao longo de um afluente do reservatório de três marias, MG. Arq. Inst. Biol. 71(2):227-232.

CUMMINS, K.W. 1992. Invertebrates. In The rivers handbook - hydrological and ecological principles (P. Calow \& G.E. Petts). Blackwell Science Ltd., Oxford, v.2, 526p.

DODDS, W.K. 2003. Misuse of organic N and soluble reactive $P$ concentrations to indicate nutrient status of surface waters. J. N. Am. Benthol. Soc. 22:171-181. http://dx.doi.org/10.2307/1467990

ESTEVES, F.A 1998. Fundamentos de limnologia. Interciência, Rio de Janeiro.

FRISSEL, C.A., LISS, W.J., WARREN, C.E. \& HURLEY, M.C. 1996. A hierarchical framework for stream habitat classification: viewing streams in a watershed context. Environ. Manag. 10:199-214. http://dx.doi. org/10.1007/BF01867358

FULLER, A. \& COWELL, B.C. 1985. Seasonal variation in benthic invertebrate recolonization of small-scale disturbances in a subtropical Florida lake. Hydrobiol. 124:211-221. http://dx.doi.org/10.1007/ $\mathrm{BF} 00015237$

GOULART, M.D.C. \& CALLISTO, M. 2003. Bioindicadores de Qualidade de Água como Ferramenta em Estudos de Impacto Ambiental. Rev. FAPAM 2:1.

HAIR, J.F., BLACK, W.C., BABIN, B.J., ANDERSON, R.E. \& TATHAM, R.L. 2009. Análise Multivariada de Dados. Editora Bookman, Porto Alegre.

HAMMER, Ø., HARPER, D. \& RYAN, P.D. 2007. PAST - Palaeontological Statistics. Version 1.89. http://folk.uio.no/ohammer/past/past.pdf(último acesso em 05/10/2004).

HARGEBY, A. 1990. Macrophyte associated invertebrates and the effect of habitat permanence. Oikos 57(3):338-346. http://dx.doi. org $/ 10.2307 / 3565963$

HARRISON, S.S.C. \& HILDREW, A.G. 2001. Epilithic communities and habitat heterogeneity in a lake littoral. J. Anim. Ecol. 70:692-707. http:// dx.doi.org/10.1046/j.1365-2656.2001.00529.x

HEINO, J. 2000. Lentic macroinvertebrates assemblages structure along gradients in spacial heterogeneity, habitat size and water chemistry. Hydrobiol. 418:229-242. http://dx.doi.org/10.1023/A:1003969217686

HIGUTI, J. \& TAKEDA, A.M. 2002. Spatial and temporal variation in densities of chironomidae larvae (Diptera) in two lagoons and two tributaries of the upper Paraná River floodplain. Brazil. J. Biol. 62(4B):807-818.

INSTITUTO BRASILEIRO DE GEOGRAFIAE ESTATÍSTICA-IBGE. 2004. Vocabulário básico de recursos naturais e meio ambiente, Rio de Janeiro.

JACKSON, M.J. 1997. Sampling methods for studying macroinvertebrates in the littoral vegetation of shallow lakes. BARS 17, the Broads Authority, Norwich, 173p.

JUNK, W.J., BAYLEY, P.B. \& SPARKS, R.E. 1989. The flood pulse concept in river-floodplain systems. Can. Spec. Pub. Fish. Aquat. Sci. 106:110-127.

KEAST, A., 1985. Planktivory in a littoral-dwelling lake fish association: prey selection and seasonality. Canadian J. Zool. 62:1289-1303. http:// dx.doi.org/10.1139/z84-186

KOLDING, J. \& ZWIETEN, P.A.M. 2006. Improving productivity in tropical lakes and reservoirs. Challenge Program on Water Food - Aquatic Ecosystems and Fisheries Review Serie 1. Theme 3 of CPWF, C/o WorldFish Center, Cairo, 139p.

KURASHOV, E.A. 1996. Invertebrates communities associated with macrophytes in Lake Ladoga: effects of environmental factors. Hydrobiol 322:49-55. http://dx.doi.org/10.1007/BF00031804
LANG, C. 1997. Oligochaetes, organic sedimentation, and trophic state: how to assess the biological recovery of sediments in lakes? Aquat. Sci. 59:26-33. http://dx.doi.org/10.1007/BF02522547

LANG, C. 1998. Contrasting responses of oligochaetes (Annelida) and chironomids (Diptera) to the abatement of eutrophication in Lake Neuchâtel. Aquat. Sci. 61:206-214. http://dx.doi.org/10.1007/ PL00001324

LELLES, C.L., SILVA, E., GRIFFITH, J.J. \& MARTINS, S.V. 2005 Perfil ambiental qualitativo na extração de areia em curso d'água. Rev. Árvore 29(003). http://dx.doi.org/10.1590/S0100-67622005000300011

LENAT, D.R. \& CRAWFORD, J.K. 1994. Effects of land use on water quality and aquatic biota of three North Carolina Piedmont streams. Hydrobiology 294 (3):185-199. http://dx.doi.org/10.1007/BF00021291

MAACK, R. 1981. Geografia física do estado do Paraná. Gravatex, Curitiba.

MARQUES, M.G.S.M., FERREIRA, R.L. \& BARBOSA, F.A.R. 1999. A comunidade de macroinvertebrados aquáticos e características limnológicas das Lagoas Carioca e da Barra, Parque Estadual do rio Doce, MG. J. Brazil. Biol. 59:203-210.

McQUEEN, D. J., POST, J.R. \& MILLS, E.L. 1986. Trophic relations in freshwater pelagic ecosystems. J. Fish. Aquat. Sci., 43:1571-1581. http:// dx.doi.org/10.1139/f86-195

MERRIT, R.W. \& CUMMINS, K.W. 1996. An Introduction to the Aquatic Insects of North America. 3. ed. Kendall, Hunt Publishing Company, Dabuqye Iowa, 862p.

METCALFE, J.L. 1989. Biological water quality assessment of running waters based on macroinvertebrates communities: history and present status in Europe. Environ. Pollut. 60:101-139. http://dx.doi.org/10.1016/02697491(89)90223-6

MILBRINK, G., TIMM, T., LUNDBERG, S. 2002. Indicative profundal oligochaete assemblages in selected small Swedish lakes. Hydrobiol. 468:53-61. http://dx.doi.org/10.1023/A:1015274323026

MOLETTA, I.M., NUCCI, J.C. \& KRÖKER, R. 2005. Carta de hemerobia de uma área de extração de areia no bairro do Umbará, Curitiba/PR/ Brasil. In XI Simpósio Brasileiro de Geografia Física Aplicada. Universidade de São Paulo.

MUGNAI, R., NESSIMIAN, J.L. \& BAPTISTA, D.F. 2010. Manual de identificação de Macroinvertebrados aquáticos do Estado do Rio de Janeiro. Technical Books Editora, Rio de Janeiro.

NASCIMENTO, L.V., ALBERTONI, E.F. \& SILVA, C.P. 2011. Fauna de coleptera associada a macrófitas aquáticas em ambientes rasos do sul do Brasil. Perspectiva 35(129):53-64.

NEIFF, J.J. 1975. Fluctuaciones anuales en la composición fitocenótica y biomasa en lagunas isleñas del Paraná Medio. Ecosur. 3(4):153-183.

NEIFF, J.J., POI DE NEIFF, A.S.G. \& CASCO, S. 2001. The effect of prolonged floods on Eichhornia crassipes growth in Paraná River floodplain lakes. Acta Limnol. Brasil. 13(1):51-60.

NESSIMIAN, J.L. \& DE LIMA, I.H.A.G. 1997. Colonização de três espécies de macrófitas por macroinvertebrados aquáticos em um brejo no litoral do estado do Rio de Janeiro. Acta Limnol. Brasil. 9(1):149-163.

NIXDORF, B. \& DENEKE, R. 1997. Why very shallow lakes are more sucessfull opposing reduced nutrient loads. Hydrobiology. 342-343:269-284. http:// dx.doi.org/10.1023/A:1017012012099

O'TOOLE, C., DONOHUE, I., MOE, S.J. \& IRVINE, K. 2008. Nutrients optima and tolerances of benthic invertebrates, the effects of taxonomic resolution and testing of selected metrics in lakes using an extensive European data base. Aquat. Ecol. 42:277-291. http://dx.doi.org/10.1007/ s10452-008-9185-8

ODUM, E.P. 2001. Fundamentos de Ecologia. 6. ed. Fundação Calouste Gulbenkian, Lisboa.

PAMPLIN, P.A.Z. 1999. Avaliação da qualidade ambiental da represa de Americana (SP-Brasil) com ênfase no estudo da comunidade de macroinvertebrados bentônicos e parâmetros ecotoxicológicos. Dissertação de Mestrado, Universidade de São Paulo, São Paulo. 
PEIRÓ, D.F. \& ALVES, R.G. 2006. Insetos aquáticos associados a macrófitas da região litoral da represa do Ribeirão das Anhumas (município de Américo Brasiliense, São Paulo, Brasil). Biota Netrop. 6(2):1-9.

PÉREZ, G.R. 1988. Guia para el estúdio de los macroinvertebrados acuáticos Del Departamento de Antioquia. Editorial Presencia Ltda, Bogotá.

POI DE NEIFF, A.S.G. \& BRUQUETAS DE ZOZAYA, I.Y. 1989. Efecto de las crecidas sobre las poblaciones de invertebrados que habitam macrófitas emergentes en las islas del rio Paraná. Rev. Hydrobiol. Tropical. 22(1):13-20.

QUIROS, R. 2002. The nitrogen to phosphorus ratio for lakes: A cause or a consequence of aquatic biology? In El Agua en Iberoamerica: De la Limnología a la Gestión en Sudamerica (A. Fernandez C. \& G. Chalar M., eds.). Programa Iberoamericano de Ciencia y Tecnologia para el Desarrollo (CYTED), Buenos Aires, p.11-26.

RAST, W. \& THORTON, J.A. 1996. Trends in eutrophication research and control. Hydrolog. Proc. 10:295-313. http://dx.doi.org/10.1002/ (SICI)1099-1085(199602)10:2<295::AID-HYP360>3.0.CO;2-F

RIVAS, Z., MEDINA, H.L., GUTIÉRREZ, J. \& GUTIÉRREZ, E. 2000. Nitrogen and phosphorous levels in sediment from tropical Catatumbo River (Venezuela). Water, Air Soil Pollut. 117:27-37. http://dx.doi. org/10.1023/A:1005189710803

ROSENBERG, D.M. \& RESH, V.H. 1993. Freshwater biomonitoring and benthic macroinvertebrates. Chapman \& Hall, New York, 488p.

SANDIN, L. \& JOHNSON, R.K. 2004. Local, landscape and regional factors structuring benthic macroinvertebrate assemblages in Swedish streams. Landsc. Ecol. 19:501-514. http://dx.doi.org/10.1023/ B:LAND.0000036116.44231.1c

SCHILLING, E.B. \& LOCKABY, B.G. 2006. Relationships Between Productivity and Nutrient Circulation Within Two Contrasting Southeastern U.S. Floodplain Forests. Wetlands 26:181-192. http://dx.doi. org/10.1672/0277-5212(2006)26[181:RBPANC]2.0.CO;2

SILANS, A.M.B.P. 2003. Redução da evaporação de açudes - O estado da arte. Rev. Brasil. Rec. Hidr. 8(2):101-109.

SILVA, F.L., PAULETO, G., TALAMONI, J. \& RUIZ, S. 2009. Categorização funcional trófica das comunidades de macroinvertebrados de dois reservatórios na região Centro-Oeste do Estado de São Paulo, Brasil. Acta Sci. Biol Sci. 31(1):73-78. http://dx.doi.org/10.4025/actascibiolsci. v31i1.331

SILVEIRA, M.P. 2004. Aplicação do Biomonitoramento para Avaliação da Qualidade da Água em Rios. Embrapa Rios Meio Ambiente, 68 p. Documentos 36 .

SMITH, V.H. 1982. The nitrogen and phosphorus dependence of algal biomass in lakes: Na empirical and theoretical analysis. Limnol. Oceanogr. 27(6):1101-1112. http://dx.doi.org/10.4319/1o.1982.27.6.1101

STATSOFT. 2005. Statistica (data analysis software system). version 7.1. www.statsoft.com
SUPERINTENDÊNCIA DE DESENVOLVIMENTO DE RECURSOS HÍDRICOS E SANEAMENTO AMBIENTAL - SUDERHSA. 2007. Plano da Bacia do Alto Iguaçu e afluentes do Alto Ribeira. Relatório de Diagnósticos: Demandas.

THIÉBAUT, G. 2008. Phosphorus and aquatic plants. Plant. Ecophysiol. 7:31-49. http://dx.doi.org/10.1007/978-1-4020-8435-5_3

THOMAZ, S.M. \& CUNHA, E.R. 2010. The Role Of Macrophytes In Habitat Structuring In Aquatic Ecosystems: Methods Of Measurement, Causes And Consequences On Animal Assemblages' Composition And Biodiversity. Acta Limnol. Brasil. 22(2):218-236. http://dx.doi. org/10.4322/actalb.02202011

TONIOLO, V., MATTIELLO, I., CAETANO, J.A. \& WOSIACK, A.C. 2001. Macroinvertebrados bentônicos como indicadores de impacto na qualidade de água do Rio Sagrado (Bacia Litorânea, PR), causada pelo rompimento do Poliduto OLAPA. In Congresso Brasileiro de Limnologia, Anais VIII Congresso Brasileiro de Limnologia. João Pessoa, p.248.

TRAYLER, K. 2000. Stream Ecology. Water \& Rivers Comission, Australia, 20p.

TRIVINHO-STRIXINO, S. \& STRIXINO, G. 1995. Larvas de Chironomidae (Diptera) do Estado de São Paulo - Guia de Identificação e Diagnose dos Gêneros. Editora da Universidade de São Carlos, São Carlos.

TUNDISI, J.G. \& MATSUMARA-TUNDISI, T. 2008. Limnologia. Oficina de Textos, São Paulo, 63p.

VANNOTE, R.L., MINSHALL, G.W., CUMMINGS, K.W., SEDELL, J.R. $\&$ CUSHING, C.E. 1980. The River Continuum Concept. J. Fish. Aquat. Sci. 37:130-137. http://dx.doi.org/10.1139/f80-017

VOLLENWEIDER, R.A. 1968. Scientific fundamentals of the eutrophication lakes and flowing waters with particular reference to nitrogen and phosphorus as factors in eutrophication. OECD Report DAS/ CJS 68:1-250.

VOLLENWEIDER, R.A. 1983. Eutrophication. Notes distributed during the II Meeting of the regional Project on the Eutrophication of Tropical Lakes. Cepis, Brazil.

WARD, J.V. 1992. Aquatic Insect Ecology 1. Biology and Habitat. New York, John Willey \& Sons.

WEATHERHEAD, M.A. \& JAMES, M.R. 2001. Distribution of macroinvertebrates in relation to physical and biological variables in the littoral zone of nine New Zealand lakes. Hydrobiology. 462:115-129. http://dx.doi.org/10.1023/A:1013178016080

WETZEL, R.G. 1984. Detrital dissolved and particulate organic carbon functions in aquatic ecosystems. Bull. of Mar. Sci. 35(3):503-509.

WETZEL, R.G. 1990. Reservoir ecosystems: conclusions and speculations. In Reservoir limnology: ecological perspectives (KW Thorton, BL Kimmel, FE Payne, eds.). John Wiley \& Sons, New York, p.227-238.

WETZEL, R.G. 2001. Limnologia. 2. ed. Saunders College Publishing, Lisboa.

WIGGINS, G.B. 1996. Larvae of the North American Caddisfly Genera (Trichoptera). 2nd. ed. University of Toronto Press, Toronto. 